\title{
YOUR CHAMBER OF COMMERCE AND YOUR CITY GOVERNMENT
}

\author{
BY HARRY A. TOULMIN, JR.' \\ Dayton, Ohio
}

$\nabla V^{\mathrm{H}}$

HY should business men be concerned with city government?

The answer is that the purpose of enlightened municipal government is to make a city a safe place in which to do business.

No farsighted executive cares or dares risk his concern or mercantile establishment to the attention of an indifferent and mismanaged city administration. The failure or success of a city in the discharge of its duties has so intimate a relationship to the prosperity of the community and its business interests that the modern executive has been compelled, from self interest at least, to take a vigorous stand on urban problems.

The logical place for business men to express themselves on the subject of city government is through their local chamber of commerce. Commercial and industrial interests largely pay the bills, directly or indirectly, for the municipal government, and they have the right to look for commensurate results.

Four hundred thousand business men of the leading commercial organizations of the western world have evidenced to the chamber of commerce of the United States an urgent, present interest in municipal affairs during the last year. And why? Because the new business-like forms of city government do these things:

The new city government puts the municipality on a sound financial basis. Proper methods of accounting, auditing and purchasing are practised. It provides honest payrolls and full-time work of the least number of useful employes. It provides a sound budget and a sane financial program of bonding and borrowing. Reduced taxes result.

The new city government provides enough water at a low cost to protect factories, stores, and buildings as well as to care for the industrial and commercial needs of a vigorous community. It motorizes its fire department and thereby reduces its insurance rates to the lowest point. This reduction is helped by the establishment of an improved building code.

A modern municipality provides adequate police for strikes, disasters, and fires. Transportation in the city is controlled in order to give workmen an opportunity to travel readily in reasonable comfort and safety to and from work. This type of transportation takes adequate care of the suburban shopping population.

Health of labor is insured by proper housing regulations, sanitation, sewerage, health rules against epidemics, etc.

${ }^{1}$ Author, "The City Manager," in the National Municipal League Series. 
Welfare departments of the new city governments insure the proper kind of amusements, provide for the education of the population on matters of health and crime, and take care of the delinquents with the least burden to the public.

Consequently, low taxes, low insurance rates, a healthy environment, efficient transportation, police and fire protection, community welfare, and best of all a splendid community spirit of co-operation flow from this type of advanced municipal administration.

Publicity for public acts, concentrated responsibility, and economy of operation have met the approval of the nation's business men, and municipal affairs as a result are the chiefest activities of commercial organizations.

Yet the Chamber of Commerce of the United States, the leading commercial organization of the world, has provided no way for co-ordinating in one great central committee this desire and need for business practice in city government. 